\title{
Ismertetés: Személyre szabott prevenció
}

\section{Personalised prevention}

Ismerteti: $\quad$ Rákosy Zsuzsa $\bowtie$

Pécsi Tudományegyetem, Általános Orvostudományi Kar, Orvosi Népegészségtani Intézet

Szerző: Ron Zimmern

Megjelenés: Personalised Prevention. In: Annual Report of the Chief Medical Officer 2016, Generation Genome London, Department of Health (2017) https://assets.publishing.service.gov.uk/government/uploads/system/uploads/attachment data/file/631043/CMO annual report generation genome.pdf

Beküldve: 2018. 08. 01.

doi: $10.24365 /$ ef.v59i4.343

Kulcsszavak: személyre szabott prevenció; genomika; biomarkerek; kockázatbecslés

Keywords: personalised prevention; genomics; biomarkers; risk assessment

Az elmúlt évtizedekben lejzajlott, nagy felbontású genomikai, proteomikai, metabolomikai kutatások eredményei lehetőséget adtak számos komplex, heterogén viselkedésű betegség ( $p l$. daganatos, szív- és érrendszeri, anyagcsere-betegségek stb.) kialakulásának és progressziójának hátterében húzódó biológiai folyamatok feltérképezéséhez és megértéséhez. A testünkben zajló molekuláris folyamatok, valamint a genetikai-epigenetikai háttér és a környezet kölcsönhatásának átfogó orvosbiológiai kutatásai paradigmaváltást eredményeztek nemcsak a gyógyításban, hanem a megelőzésben is. A Humán Genom, Epigenom, Mikrobiom Projektek eredményeinek transzlációja az orvostudomány különböző területeire alapot nyújt az egyes betegségekre való hajlam meghatározásához, markerként funkcionálnak a betegségek diagnózisához. A betegségek molekuláris eltéréseken alapuló osztályozása segíti a hatékony és specifikus kezelés kiválasztását, ezáltal növelve az alkalmazott terápia hatékonyságát.

A személyre szabott prevenció a betegségek megelőzésére irányul az egyén szintjén. A genomika kontextusában ez azt jelenti, hogy genetikai információkat használnak a különböző betegségek kialakulása szempontjából magas kockázatú egyének azonositására, lehetővé téve a célzott, egyénre szabott megelőző intézkedések, stratégiák kidolgozását. A prevenció területén a genomikai információk eredményes használata egyelőre a ritka betegségek esetében bizonyult hatékonynak, ahol általában egy genetikai lókuszt érintő, magas penetranciájú alteráció áll a betegség kialakulásának hátterében. A komplex betegségek esetében a genomikai információk prevenciós használhatóságáról még nincs meggyőző bizonyíték, mivel ezek a betegségek több lókuszt érintő genetikai és epigenetikai eltérések, továbbá környezeti és életmódbéli tényezők eredőjeként alakulnak ki. Ebből kifolyólag a megfelelő szenzitivitású, specificitású, prediktív genomi, környezeti és további biológiai markerek kombinációjára lenne szükségünk a betegség kialakulása kockázatának becslésére.

Ugyanakkor a biomarkerek nemcsak az egyén szintjén alkalmazhatók kockázatbecslésre, hanem lehetővé teszik új prognosztikai alcsoportok felállítását, továbbá fontos szerepet játszanak a terápia megválasztásában is. Az extrém magas kockázatú személyeknek jellemzően egy gént érintő eltérésük van, ez az emlődaganatok esetében a BRCA1 vagy BRCA2, a vastagbéldaganatoknál az FPC vagy HNPCC gének alterációit jelentik. A biomarkerek további klinikai alkalmazására jó példa az 
epidermalis növekedési faktor (EGFR) gén mutációjának, illetve expressziójának vizsgálata, amely nemcsak a terápia megválasztásában játszik szerepet, hanem prognosztikai jelentőségú is. Tüdődaganatok onkológiai kezelésében az anti-EGFRterápia látványos eredményeket hozott, de ahhoz, hogy ki lehessen választani azokat a betegeket, akiknél ez a kezelés hatásos, a patológiai minták célzott molekuláris vizsgálata (EGFR-immunhisztokémia, EGFR-mutáció) szükséges, így elkülönítve az EGFR-pozitív alcsoportba tartozó eseteket, amelyek gerfitinib- vagy erlotinibkezelésre reagálnak. A kandidáns molekuláris alterációk detektálása mellett egyre nagyobb szerepet kap az alacsony penetranciájú genetikai, epigenetikai, génexpreszsziós, metabolomikai és mikrobiom-variációk együttes vizsgálata a betegség kockázatának kitett személyek azonosításában, illetve a már meglévő betegségek klinikai csoportosításában. A nagy felbontású vizsgálatok adatait a betegségek klinikopatológiai paramétereivel összehasonlítva lehetőség nyílik olyan molekuláris klaszterek azonosítására, amelyek eltérései szoros korrelációt mutatnak a betegség progressziójával. A nagy felbontású microarray génexpressziós adatok validált klinikai alkalmazására jó példa az Oncotype Dx (https://www.breastcancercare.org.uk/ oncotype-dx) nevű, 21 gént vizsgáló teszt, amely személyre szabott prediktív és prognosztikus eredménnyel segíti a korai emlőrákos betegekkel kapcsolatos terápiás döntést.

\section{TANULSÁGOK A HAZAI SZAKEMBEREK SZÁMÁRA}

A személyre szabott prevenció a népegészségügyi beavatkozásokat precízebbé és hatékonyabbá teszi. A célzott, illetve nagy felbontású technikákat alkalmazó kutatásoknak köszönhetően már számos olyan molekuláris alterációt azonosítottak, amely betegség kialakulására hajlamosít. A molekuláris eltéréseken és variációkon, valamint környezeti markereken nyugvó egyéni kockázatbecslés, majd azt követően a megfelelő primer prevenciós lépések révén lehetővé válik a betegség kialakulásának megelőzése. Ezenkívül a molekuláris klasszifikáció alapot nyújt a már kialakult betegségek eredményesebb kezelésére. Remélhetőleg a környezeti és/vagy biológiai markerek használatán alapuló, személyre szabott prevenció a jövőben hozzájárul a ritka betegségek, a daganatos betegségek és további komplex betegségek megelőzéséhez. 